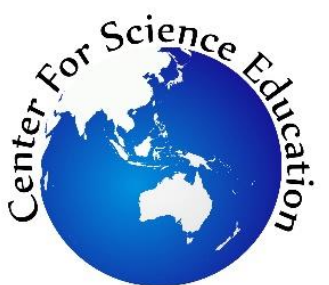

Tersedia online di EDUSAINS

Website: http://journal.uinjkt.ac.id/index.php/edusains

EDUSAINS,11 (2), 2019, 203-212

Research Artikel

\title{
KREATIVITAS DAN PENGETAHUAN SISWA PADA MATERI ASAM-BASA MELALUI PENERAPAN PROJECT BASED LEARNING DENGAN PRODUK KREATIF TERI PUTER
}

\author{
STUDENTS' CREATIVITY AND KNOWLEDGE ON ACID-BASE TOPIC THROUGH THE \\ APPLICATION OF PROJECT-BASED LEARNING WITH TERI PUTER CREATIVE PRODUCTS
}

\section{Nailissatin Khumaeroh, Woro Sumarni}

Universitas Negeri Semarang

worosumarni@mail.unnes.ac.id

\begin{abstract}
Creativity is one of the most needed competencies in the 21 st century. This study aims to analyze students' creativity and knowledge on acid-base material through the application of Project Based Learning with Teri Puter Creative Products. The study was conducted at SMA Negeri 1 Bae Kudus with 35 research subjects in class XI MIPA 6 in the 2018/2019 school year. Data collection techniques using test and nontest instruments that have been declared valid and reliable. The results showed as many as $74 \%$ of students were in creative criteria and were very creative with the highest percentage in the originality indicator and the lowest percentage in the fluency indicator, while for the ability of knowledge by $40 \%$ who had good criteria and very good. The highest achievement is on the indicator to calculate the $\mathrm{pH}$ of acid-base solution and the lowest achievement on the indicator to calculate the concentration of $\left[\mathrm{H}^{+}\right]$and $\left[\mathrm{OH}^{-}\right]$in the solution. Positive responses are given by students with project based learning that has been applied.
\end{abstract}

Keywords: Creativity; Knowledge; Project Based Learning; Teri Puter

\begin{abstract}
Abstrak
Kreativitas merupakan salah satu kompetensi yang amat dibutuhkan pada abad ke-21. Penelitian ini bertujuan untuk menganalisis kreativitas dan pengetahuan siswa pada materi asam-basa melalui penerapan Project Based Learning dengan Produk Kreatif Teri Puter. Penelitian dilaksanakan di SMA Negeri 1 Bae Kudus dengan subjek penelitian sebanyak 35 siswa kelas XI MIPA 6 pada tahun ajaran 2018/2019. Teknik pengumpulan data menggunakan instrumen tes dan non tes yang telah dinyatakan valid dan reliabel. Hasil penelitian menunjukkan sebanyak $74 \%$ siswa berada pada kriteria kreatif dan sangat kreatif dengan persentase tertinggi pada indikator originality dan persentase terendah pada indikator fluency, sedangkan untuk kemampuan pengetahuan sebesar $40 \%$ yang berkriteria baik dn sangat baik. Pencapaian tertinggi yaitu pada indicator menghitung $\mathrm{pH}$ larutan asam-basa dan pencapaian terendah pada indicator menghitung konsentrasi $\left[\mathrm{H}^{+}\right]$dan $\left[\mathrm{OH}^{-}\right]$dalam larutan. Tanggapan positif diberikan oleh siswa dengan project based learning yang telah diterapkan.
\end{abstract}

Kata Kunci: Kreativitas; Pengetahuan; Project Based Learning; Teri Puter

Permalink/DOI: http://doi.org/10.15408/es.v11i2.11494 


\section{PENDAHULUAN}

Siswa dalam hidup di abad ke-21 sekarang ini, tidak cukup dibekali dengan kemampuan membaca, menulis dan berhitung saja, namun dibutuhkan keterampilan lain diantaranya keterampilan yang dikenal dengan istilah "Four C's" yaitu Communication, Collaboration, critical thinking, and Creativity ( National Education Association, 2012). Oleh karena itu, proses pembelajaran dituntut agar membekali siswa dengan keterampilan-keterampilan tersebut melalui pengalaman belajar yang beragam, menantang, dan menyenangkan.

Kreativitas sebagai salah satu keterampilan yang harus harus dimiliki oleh siswa adalah kemampuan untuk menghasilkan gagasan/ide yang orisinil, dapat berupa sintesis pemikiran yang hasilnya dapat berbentuk produk seni, sastera, produk ilmiah yang bersifat prosedural atau metodologis. Kreativitas sebagai salah satu kemampuan berpikir divergen diperlukan oleh siswa dalam memecahkan permasalahan dan menemukan konsep baru dalam kegiatan belajarnya serta memiliki kemampuan menggunakan berbagai macam alternatif solusi terhadap permasalahan yang dihadapinya (Artikasari \& Saefudin, 2017; Runco \& Acar, 2012).

Pentingnya kreativitas tertera dalam sisdiknas No. 20 Tahun 2003, yang menyatakan bahwa melalui pendidikan, potensi peserta didik diharapkan dapat berkembang untuk menjadi manusia yang bertakwa, berakhlak mulia, cakap, kreatif, juga mandiri. Kreativitas tersebut bisa ditandai dengan kemampuan berpikir kreatif, menghasilkan produk kreatif, bersikap dan berperilaku kreatif (Nuswowati et al., 2017).

Individu dengan keterampilan kreatif yang lebih tinggi terbukti memiliki tingkat ketahanan yang lebih tinggi ketika dihadapkan dengan pengalaman yang menantang, dan fleksibilitas yang lebih besar dalam kaitannya dengan tuntutan kesulitan hidup sehari-hari (Lynch et al., 2013). Individu kreatif dianggap lebih percaya diri dibandingkan dengan mereka yang memiliki keterampilan kreatif yang kurang berkembang (Bungay \& Vella-Burrows, 2013).
Kreativitas tidak saja bergantung kepada potensi bawaan tiap individu, tetapi bisa dibekalkan melalui lingkungan belajar yang merangsang kreativitas siswa (Byrge \& Tang, 2015). Rangsangan berupa bimbingan dan motivasi terhadap munculnya kreativitas bisa berasal dari sekolah, lingkungan keluarga, maupun lingkungan masyarakat. Kesempatan bereksperimen dan bereksplorasi, juga harus disediakan untuk merangsang munculnya pemikiran kreatif. Dengan demikian aspek-aspek seperti fluency, flexibility, originality dan elaboration dapat dikembangkan dalam diri seseorang.

Kemampuan kognitif atau pengetahuan seseorang sering dikaitkan dengan kreativitas, karena berpikir kreatif adalah kemampuan kognitif untuk menyelesaikan masalah secara divergen yang menekankan pada aspek kemampuan berpikir lancar, berpikir luwes, berpikir orisinil/asli, dan kemampuan elaborasi/merinci (Lewis \& Lovatt, 2013). Pengetahuan adalah hasil "tahu" dan hal ini terjadi setelah seseorang mengadakan pengamatan terhadap objek tertentu menggunakan panca inderanya. Kreativitas akan diperoleh seseorang jika seseorang berupaya mengatasi masalah dalam kehidupannya. Tentu saja, kemampuan seseorang dalam mengatasi permasalahan tersebut sangat bergantung pada kemampuan intelektual seseorang.

Selama ini, pada proses pembelajaran di sekolah siswa kurang diberi kesempatan untuk memikirkan dan mengembangkan potensi-potensi yang dimiliki yang berakibat pada rendahnya kreativitas siswa (Kenedi, 2017). Tentu saja, kreativitas memang seharusnya dilatihkan dan diberdayakan secara optimal, sehingga perlu upaya untuk memberikan pembekalan kepada siswa oleh guru. Salah satu model pembelajaran yang terbukti mampu membekali dan meningkatkan kreativitas siswa adalah project based learning. Model ini cocok untuk siswa dari tingkat sekolah dasar hingga universitas (Jacques, 2017). Project based learning memfasilitasi siswa untuk berkolaborasi dalam meningkatkan pengetahuan konten, dalam menerapkan pengetahuan sebelumnya, dalam memperoleh beragam keterampilan dan dapat mengintegrasikan beberapa disiplin ilmu untuk 
membuat proyek (Capraro \& Slough, 2013; Coyne et al., 2016).

Hasil penelitian juga menunjukkan bahwa project based learning, selain mampu membangun pengetahuan dalam diri siswa, menciptakan pembelajaran yang menarik minat siswa untuk belajar lebih lanjut, meningkatkan keterampilan psikomotorik, serta meningkatkan keterampilan berpikir kritis dan kreatif siswa (Sumarni, 2015; Sumarni et al., 2016; Wijayati et al., 2018). Melalui berbagai proyek yang ditugaskan kepada siswa, guru dapat mengamati kreativitas siswa dalam pembelajaran. Oleh karena itu, untuk mengetahui sejauh mana kreativitas siswa dapat terbentuk melalui proses pembelajaran di sekolah, maka dirasa perlu untuk menerapkan project based learning dengan tugas proyek membuat poster berbasis komputer untuk selanjutnya disebut Teri Puter.

Media poster adalah suatu media visual yang sederhana, menarik, dan mudah dipahami. Poster berfungsi untuk menyampaikan pesan yang dituangkan dalam simbol-simbol komunikasi visual (Rizawayani et al., 2017). Ilustrasi menggunakan gambar memungkinkan lebih menarik perhatian, memperjelas materi, dan mempercepat penyampaian informasi (Rikmasari \& Wati, 2017). Poster berfungsi sebagai media untuk menarik perhatian agar pesan, gagasan, dan informasi yang ingin disampaikan tidak mudah dilupakan (Yusandika et al., 2018). Poster yang merupakan pelengkap dari pembelajaran yang diterapkan mempunyai keunggulan diantaranya yaitu (1) dapat diproduksi dalam durasi waktu yang tidak terlalu lama, (2) berupa tulisan yang singkat, padat informasi dengan kombinasi warna yang menarik, (3) tidak membutuhkan waktu lama untuk memahaminya, sehingga mempermudah siswa dalam pembelajaran, (4) penggunaannya tidak memerlukan alat penunjang (Rikmasari \& Wati, 2017).

Teri Puter dibuat sebagai pengganti laporan praktik pembuatan produk yang telah dikerjakan. Pemanfaatan komputer ini sebagai salah satu sarana mendekatkan siswa akan literasi teknologi yang juga dituntut pada pembelajaran pada abad ke-21. Dengan adanya tugas ini para siswa dibiasakan untuk memanfaatkan teknologi komputer yang mampu menawarkan kemudahan dan sekaligus tantangan dalam dunia pendidikan.

Memanfaatkan teknologi komputer ini, laporan praktikum yang biasanya disusun berupa karya tulis yang sudah baku tata-cara penulisannya berisikan judul, tujuan, alat dan bahan, cara kerja, hasil pengamatan, pembahasan, kesimpulan dan daftar pustaka, diubah menjadi suatu bentuk poster yang menggambarkan tentang percobaan yang dilakukan, di desain sedemikian rupa sehingga menjadi suatu tampilan yang menarik dengan memanfaatkan komputer. Dengan cara ini, diharapkan kreativitas siswa akan terbangun, pengetahuan siswa akan konsep asam-basa meningkat, dan keterampilan siswa dalam memanfaatkan komputer juga meningkat.

Adapun tugas proyek Teri Puter ini diawali dengan pembuatan produk kreatif terkait konsep asam-basa yaitu membuat mangosten soap sebagai contoh larutan basa dan Bilimby Sirup sebagai contoh larutan asam. Setelah produk dihasilkan, siswa menguji pHnya dengan indikator universal dan indikator asam basa dari bahan alam, menghitung $\mathrm{pH}$ larutan asam/basa jika diketahui data konsentrasinya.

Pembuatan produk kreatif diharapkan dapat merangsang kreativitas siswa dalam membuat produk yang baik dan bermutu. Setelah selesai membuat produk, siswa juga ditugasi mengkomunikasi proses pembuatan produknya dalam bentuk poster untuk memberikan pengalaman dalam menjelaskan konsep yang terkandung dalam produk yang dibuat dengan memanfaatkan teknologi komputer. Oleh karena itu, mengingat pentingnya pembelajaran untuk merangsang kreativitas, meningkatkan pengetahuan akan konsep asam-basa, dan keterampilan siswa dalam memanfaatkan komputer, maka pada penelitian ini diterapkan pembelajaran berbasis proyek dengan produk kreatif poster berbasis komputer (Teri Puter) untuk selanjunya dianalisis hasil pembelajarannya berupa kreativitas dan pengetahuan siswa terkait konsep asam-basa. 


\section{METODE}

Penelitian ini dilaksanakan di SMA N 1 Bae Kudus, Jawa Tengah dengan desain one shot case study. Subjek penelitian adalah 35 siswa kelas XI MIPA 6, terdiri atas 10 siswa putra dan 25 siswa putri yang dipilih secara purposive sampling. Berkaitan dengan tujuan penelitian di atas, maka teknik pengumpulan data menggunakan: (1) Soal tes untuk mengukur pengetahuan berupa soal pilihan ganda beralasan (two tier) berjumlah 20 soal. Indikator soal tes pengetahuan meliputi pengertian asam dan basa, penulisan persamaan reaksi asam-basa, menghubungkan kekuatan asam atau basa dengan derajat ionisasi dan tetapan kesetimbangan ionisasinya, dan menghitung $\mathrm{pH}$ larutan asam/basa dari data konsentrasi. (2) lembar penilaian untuk menilai kreativitas didasarkan pada penilaian kreativitas figural yaitu penilaian untuk mengetahui kreativitas pada diri individu dengan cara melihat hasil kerja siswa berupa poster. Penilaian ini mengukur aspek originality, fluency, flexibility, dan elaboration dengan 10 pernyataan dalam skala Likert 1-4. (3) Angket respon siswa terhadap model pembelajaran yang diterapkan meliputi aspek ketertarikan, pemahaman, inovasi dan kreativitas, sifat positif, dan keefektifan berjumlah 18 pernyataan, dan (4) wawancara mendalam untuk melengkapi hasil penilaian pengetahuan dan kreativitas, dengan indikator pertanyaan bagaimana dan mengapa atas jawaban 6 siswa terpilih masing-masing 2 siswa pada kategori tinggi, sedang dan rendah.

Soal tes pengetahuan telah dinyatakan valid oleh ahli dan telah diujicobakan menghasilkan nilai reliabilitas $r_{11}$ sebesar 0,78. Lembar penilaian kreativitas mencakup 4 aspek telah dinyatakan valid oleh ahli dan hasil uji reliabitas menggunakan inter rater reliability diperoleh nilai $\mathrm{r}_{11}$ sebesar 0,806. Demikian pula untuk angket tanggapan siswa yang meliputi 18 pernyataan yang mencakup aspek ketertarikan, pemahaman, inovasi dan kreativitas, sifat positif, dan keefektifan.

Teknik analisis data untuk mengukur pengetahuan merujuk pada kriteria hasil belajar kognitif yang disajikan pada Tabel 1. Kriteria kreativitas siswa disajikan pada Tabel 2.
Tabel 1. Kriteria Pengetahuan siswa

\begin{tabular}{ll}
\hline Nilai siswa & Kriteria \\
\hline $\mathbf{8 5}<\mathbf{X} \leq \mathbf{1 0 0}$ & Sangat Baik \\
$\mathbf{7 5}<\mathbf{X} \leq \mathbf{8 5}$ & Baik \\
$\mathbf{5 0}<\mathbf{X} \leq \mathbf{7 5}$ & Cukup \\
$\mathbf{0}<\mathbf{X} \leq \mathbf{5 0}$ & Kurang \\
\hline
\end{tabular}

Tabel 2. Kriteria Kreativitas Siswa

\begin{tabular}{ll}
\hline Skor siswa & Kriteria \\
\hline $\mathbf{3 5}<\mathbf{X} \leq \mathbf{4 0}$ & Sangat Kreatif \\
$\mathbf{3 0}<\mathbf{X} \leq \mathbf{3 5}$ & Kreatif \\
$\mathbf{2 0}<\mathbf{X} \leq \mathbf{3 0}$ & Cukup Kreatif \\
$\mathbf{1 0}<\mathbf{X} \leq \mathbf{2 0}$ & Kurang Kreatif \\
\hline
\end{tabular}

Pembuatan produk kreatif Teri Puter ini menuntut siswa untuk mengoperasikan berbagai aplikasi desain yang ada di komputer sesuai dengan kemampuan masing-masing siswa.

\section{HASIL DAN PEMBAHASAN}

Pembelajaran materi asam-basa digunakan sebagai wahana dalam menerapkan pembelajaran berbasis proyek dengan produk kreatif Teri puter ini. Hal ini didasarkan pada kenyataan bahwa pada pembelajaran materi ini memungkinkan melakukan pembelajaran tidak hanya di kelas atau di laboratorium saja, namun memungkinkan juga siswa beraktivitas di luar kelas. Sebagaimana Kompetensi Dasar yang tercantum dalam Silabus Mapel Kimia Kelas X: 3.10 Memahami konsep asam dan basa serta kekuatannya dan kesetimbangan pengionannya dalam larutan dan 4.10 Menentukan trayek perubahan $\mathrm{pH}$ beberapa indikator yang diekstrak dari bahan alam, maka selain melakukan pembelajaran teori di kelas, praktik di laboratorium, siswa juga diberikan tugas untuk melakukan percobaan terkait produk yang bermanfaat untuk kehidupan sehari-hari yang bersifat asam dan basa.

Kami menggunakan lembar penilaian produk dan wawancara untuk mengumpulkan data tentang kreativitas. Penilaian dilakukan dengan melihat produk kreatif Teri Puter yang dihasilkan oleh siswa, sedangkan wawancara digunakan untuk mengungkap lebih jauh tentang kreativitas siswa dari aspek kelancaran, fleksibilitas, orisinalitas, dan 
kebaruan dari produk yang dihasilkan (Kaufman et al., 2008).

Proses pemantauan, kami meminta siswa mengisi buku catatan kemudian membimbing mereka selama pembuatan produk. Sementara dalam langkah evaluasi, kami menilai dan menganalisis kelemahan dan kelebihan dari produk Teri Puter karya siswa diperkuat melalui wawancara mendalam pada perwakilan kelompok siswa. Gambar 1 adalah contoh hasil tugas proyek berupa poster berbasis komputer.

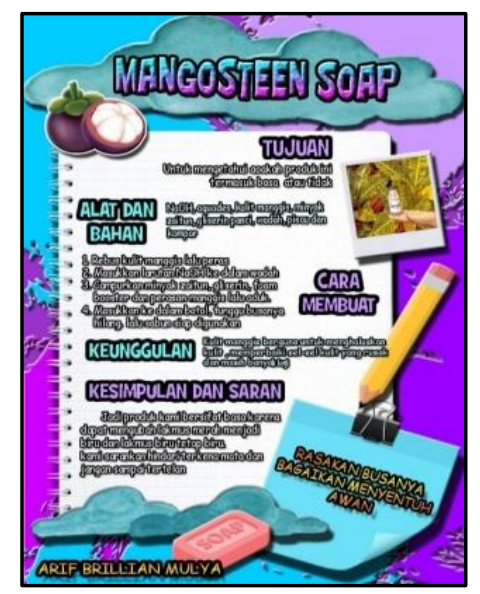

Gambar 1. Contoh Poster berbasis Komputer "Teri Puter" Hasil Karya Siswa

Penilaian produk kreatif Teri Puter yang dihasilkan oleh semua siswa dilakukan oleh 3 penilai. Hasil penilaian kreativitas siswa disajikan pada Gambar 2.

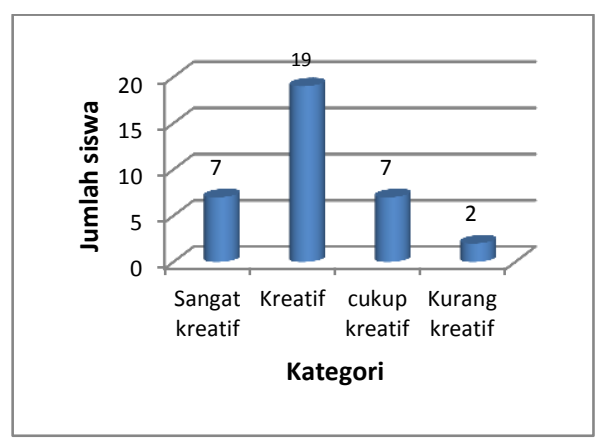

Gambar 2. Hasil Penilaian Kreativitas Siswa

Gambar 2 menunjukkan bahwa sebagian besar siswa berada pada kategori kreatif $(74 \%)$. Hal ini sesuai dengan yang diperoleh (Indriajati \& Ngazizah, 2018), namun masih banyak juga siswa yang tergolong cukup dan kurang kreatif. Hal ini bisa dikarenakan siswa belum terbiasa dalam mendesain poster menggunakan komputer sehingga berpengaruh dengan hasil produknya. Hal tersebut sejalan dengan yang disampaikan Aini et al (2018), bahwa kreativitas sebagian siswa masih dalam kategori cukup kreatif dikarenakan siswa belum terbiasa mengungkapkan berbagai macam ide dalam pembelajaran sehingga cara berfikir siswa untuk mengungkapkan berbagai ide belum bisa berkembang baik.

Analisis penilaian kreativitas pada produk kreatif juga dilakukan pada setiap indikatornya. Hasil penilaian kreativitas siswa pada setiap indikator disajikan pada Tabel 3.

Tabel 3. Hasil Penilaian Kreativitas Siswa melalui Produk Teri Puter

\begin{tabular}{|c|c|c|c|c|}
\hline \multirow[t]{2}{*}{ Hasil } & \multicolumn{4}{|l|}{ Indikator } \\
\hline & $\begin{array}{l}\text { Originali } \\
\text { ty }\end{array}$ & $\begin{array}{l}\text { Fluenc } \\
y\end{array}$ & $\begin{array}{l}\text { Flexibili } \\
\text { ty }\end{array}$ & $\begin{array}{l}\text { Elaboratio } \\
n\end{array}$ \\
\hline $\begin{array}{l}\text { Rerata } \\
\text { skor }\end{array}$ & 6,74 & 6,51 & 6,70 & 6,62 \\
\hline $\begin{array}{l}\text { Katego } \\
\text { ri }\end{array}$ & Kreatif & Kreatif & Kreatif & Kreatif \\
\hline
\end{tabular}

kreativitas siswa setelah penerapan project based learning berada pada kategori kreatif di semua indikator. Hal ini sesuai dengan hasil penelitian Sumarni et al (2016) bahwa penerapan project based learning mampu meningkatkan keterampilan berpikir kreatif siswa pada kategori baik.

Penilaian pada indikator originality, didasarkan produk kreatif dan poster yang dihasilkan yaitu poster harus baru atau unik, baik dalam desain poster; informasi isi poster; judul poster. Persentase tingkat ketercapaian indikator originality berada pada kriteria kreatif. Hal ini menunjukkan siswa telah mampu dibangun kemampuan kreatifnya khususnya pembekalan untuk memproduksi sesuatu yang bersifat orisinil. Penilaian pada indikator fluency, ditekankan pada penyajian poster yaitu poster disajikan dengan informasi yang jelas, sesuai dengan konten yang dipelajari, tulisan poster harus terbaca jelas, serta di dalam poster harus berisi segala sesuatu terkait dengan produk kreatif yang telah dibuat.

Indikator flexibility, dinilai berdasarkan kemampuan siswa dalam menggunakan lebih dari satu aplikasi desain poster ketika mengalami 
kesulitan dalam membuat poster, penilaian juga dilakukan pada saat siswa menyediakan alat, bahan, dan cara kerja pengganti ketika menemui masalah dalam membuat produk. Pada indikator elaboration, siswa dinilai melalui detail tampilan poster berupa rincian isi poster, kombinasi gambar, warna, ukuran, dan bahasa pada poster yang dibuat. Indikator ini perlu karena dalam mengkombinasikan warna pada poster mampu menciptakan suasana poster lebih hidup, dan terlihat lebih menarik. Pengombinasian gambar juga perlu dilakukan karena mampu memunculkan imaginasi, memfokuskan pikiran, konsentrasi, serta mengaktifkan otak (Rizawayani, Sari, \& Safitri, 2017) (Rikmasari \& Wati, 2017).

Walaupun semua indikator berada pada kategori kreatif, namun jika dilihat dari rerata skor diperoleh skor tertinggi yaitu pada indikator originality, dimana siswa dalam berfikir kebaruan, antara lain ditunjukkan dengan membuat kombinasi-kombinasi yang tidak lazim dari bagianbagian atau unsur-unsur dalam poster. Walaupun masih terdapat beberapa kekurangan pada poster yang dihasilkan namun dari segi desain, isi bahkan judul menandakan kebaruan.

Rerata tertinggi selanjutnya yaitu pada indikator flexibility, dimana siswa dalam berfikir luwes ini juga termasuk kedalam kriteria kreatif, ditunjukkan dari pemikiran siswa yang tidak terpaku pada satu pemecahan masalah, siswa mampu membuat teri puter dengan cara dan kemampuannya sendiri. Bukan hanya pada pembuatan poster, namun pada saat pembuatan produk yang bersifat asam dan basa juga menerapkan berfikir fleksibel seperti mampu menyediakan alat, bahan, dan cara kerja pengganti jika terjadi masalah.

Indikator elaboration juga berada pada kategori kreatif namun dengan tingkat pencapaian di bawah indikator flexibility dan originality. Hal ini menunjukkan siswa sudah memiliki keterampilan berfikir rinci yang ditunjukkan dengan kemampuan siswa mengembangkan suatu produk kreatif yang mengandung asam atau basa; dan dalam menyampaikan langkah kerja dalam poster mampu memperinci detil-detil secara runtut dari produk yang digambarkan sehingga menjadi lebih menarik. Pada umumnya, siswa menampilkan kombinasi gambar, warna, serta ukuran yang telah ditetapkan dengan baik, dan bahasa yang digunakan sudah memadai, namun ada beberapa poster yang kurang-tepat dalam mengkombinasikan warna dan penggunaan kalimat yang terlalu panjang.

Ketercapaian indicator fluency yang paling rendah diantara keempatnya. Hal ini menunjukkan bahwa hanya sebagian siswa yang telah mampu berpikir lancar dalam menyusun isi poster dengan tingkat keterbacaan yang baik. Karena beberapa siswa memberikan informasi yang kurang jelas dan kurang sesuai dengan produk yang dibuatnya.

Hal ini selaras dengan hasil wawancara kepada beberapa siswa dimana siswa yang dikategorikan sebagai kelompok tinggi, sedang dan rendah ini beranggapan sama, yaitu pembelajaran berbasis proyek dapat meningkatkan kreativitas siswa khususnya dengan menghasilkan sebuah produk kreatif poster berbasis komputer atau teri puter, semua responden beranggapan bahwa penugasan ini sangat menarik, seru, unik dan tentunya mampu menambah kreativitas dalam diri setiap siswa. Seperti salah satu cuplikan berikut:

Peneliti: kalian pernah denger pembelajaran
project based learning? A 1, 2, 3: belum bu

Peneliti : nah, yang kalian lakukan kemarin itu namanya model project based learning. Pembelajarannya berbasis proyek. Pertama, kalian ibu beri Proyek yaitu pembuatan produk yang bersifat asam-basa, dan yang kedua yaitu poster sebagai pengganti buku laporan. Apakah bisa digunakan untuk mengembangkan keterampilan kreativitas kita tidak?

A1, a2, a3 : sangat bisa bu, apalagi pas pembuatan posternya itu sangat memerlukan ide-ide kreatif yang muncul.

Namun di wawancara berikutnya, peneliti merasakan keganjalan terhadap satu siswa ini sejak awal, dan setelah peneliti telusuri lebih dalam ternyata siswa tersebut kurang setuju dengan pemberian pembelajaran berbasis proyek, seperti cuplikan berikut: 
Peneliti : pembelajaran berbasis proyek ini menurut kalian bagaimana?

B1: jujur awalnya si berat, membebani, tapi setelah dijalani ya bisa, apalagi pas pembuatan poster ini kan kita memang di haruskan kreatif gitu bu, dan menarik

Peneliti: iya, terus kamu B2

B2: Kan pembelajaran ini kan banyak di proyek, apalagi proyek yang membuatnya bareng-bereng kan bu kelompokan?

Peneliti : oh yang proyek pertama?

B2: saya kan mondok jadikan gak boleh keluar, jadi saya gak terlalu suka waktu disuruh membuat proyek itu.

Peneliti: jadi kekurangannya kamu itu dalam mengakses bertemu dengan kelompok mu itu susah. Terus untuk proyek kedua saat membuat poster?

B2: proyek kedua ya gak papa bu, karena bisa disambi disekolah.

Peneliti: menambah kreativitas kalian tidak?

\section{B1: iya jadi bisa membuat posternya}

Peneliti : iya betul, tidak hanya itu, kan pada proyek pertama, ibu suruh kalian membuat produk yang mengandung asam-basa, nah ibu kan tidak memberi tahu sama sekali, kalian cari tahu sendiri cara buatnya gimana, alat bahannya apa, dll. Jadi menurut kalian bisa mengasah ide kreatif kalian tidak?

B1: iya bu bisa mengasah kreativitas kita banget.

Melihat hasil yang telah diperoleh di atas, menunjukkan bahwa pada dasarnya semua siswa telah memiliki kreativitas dengan tingkatan yang berbeda, sehingga yang amat dibutuhkan adalah bagaimana agar kreativitas yang telah ada pada diri masing-masing individu tersebut dapat berkembang dengan optimal. Project based learning dengan produk kreatif yang diterapkan, terbukti mampu mengembangkan kreativitas siswa pada kriteria kreatif (Bell, 2010). Produk kreatif ini dapat digunakan untuk menilai tinggi rendahnya kreativitas seseorang, karena produk kreatif tidak lahir hanya karena kebetulan, melainkan melalui serangkaian proses kreatif yang menuntut dorongan atau motivasi, keinginan dari dalam diri, kesempatan, dan keterampilan untuk berkembang menjadi lebih baik. Hasil analisis data juga telah berhasil mendeskripsikan kemampuan pengetahuan siswa pada materi asam-basa setelah penerapan project based learning. Hasil yang diperoleh disajikan pada Gambar 3.

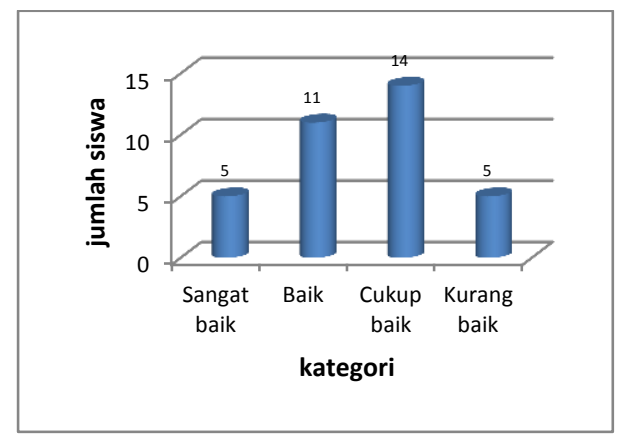

Gambar 3. Profil pengetahuan siswa pada materi asam-basa

Hasil analisis pengetahuan siswa secara umum berkriteria cukup baik dengan nilai rata-rata sebesar 58 dari nilai total 100. Hasil ini tidak sesuai dengan pendapat yang menyatakan bahwa peningkatan aktivitas siswa melalui tugas proyek akan membuat siswa memahami konten lebih dalam. Namun demikian, hasil yang diperoleh tersebut sesuai dengan hasil penelitian (Rikmasari \& Wati, 2017) yang menyatakan bahwa tidak terdapat hubungan yang signifikan atau kurang adanya pengaruh antara media visual gambar poster dengan pemahaman materi siswa (pengetahuan).

Pada penelitian ini diperoleh hasil pengetahuan siswa masih berada pada kategori cukup baik. Perolehan hasil penelitian ini dimungkinkan siswa lebih fokus dengan tugastugas proyek yang dibebankan, sehingga pemahaman konsep siswa menjadi terganggu. Hasil yang diperoleh di atas, ternyata sesuai dengan respon siswa pada aspek pemahaman yang menunjukkan masih ada beberapa siswa yang belum mampu memperoleh pemahaman setelah penerapan model project based learning,hal ini menunjukkan pembelajaran berbasis proyek yang 
diterapkan masih memiliki keterbatasan dan belum mampu memfasilitasi terbentuknya kreativitas pada semua siswa. Pengetahuan siswa untuk setiap indicator pencapaian kompetensi dapat dilihat pada Gambar 4.

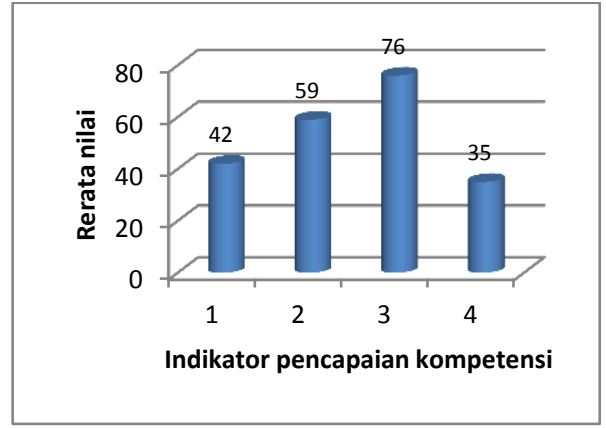

Gambar 4 Capaian pengetahuan siswa tiap indikator.

Keterangan gambar:

Indikator 1:Menganalisis teori asam basa berdasarkan konsepArchenius, Bronsted-Lowry dan Lewis

Indikator 2:Menganalisis $\mathrm{pH}$ asam dan basa berdasarkan trayek perubahan warna

Indikator 3:Menghitung $\mathrm{pH}$ larutan asam-basa

Indikator 4:Menghitung konsentrasi $\left[\mathrm{H}^{+}\right]$dan $\left[\mathrm{OH}^{-}\right]$dalam larutan

Berdasarkan Gambar 4, tampak bahwa persentase ketercapaian paling rendah di bandingkan dengan indicator lain adalah indicator 4. Perolehan nilai siswa rendah disebabkan karena banyak siswa yang kurang paham cara menentukan nilai $\left[\mathrm{H}^{+}\right]$dan $\left[\mathrm{OH}^{-}\right]$suatu larutan secara bersamaan, sehingga banyak siswa yang menjawab asal-asalan bahkan kosong. Hal ini seperti hasil penelitian Andiyana et al. (2018) dan Ariani et al., 2019) yang menyatakan bahwa siswa sering lupa sehingga tidak mampu memberikan jawaban yang diinginkan serta siswa belum terbiasa menghadapi soal-soal yang berbeda dengan soal biasanya. Hasil yang diperoleh pada penelitian ini ternyata tidak sejalan dengan hasil penelitian terdahulu, dimana penerapan project based learning mampu menjadikan hasil belajar kognitif siswa menjadi lebih baik (Sumarni et al., 2019; Prabowo, 2012). Dengan kata lain penerapan model project based learning dalam penelitian ini tidak secara nyata menjadikan pengetahuan siswa menjadi lebih baik, walaupun siswa senang dengan pembelajaran berbasis proyek dengan menghasilkan produk kreatif teri puter yang diterapkan pada materi asambasa.

\section{PENUTUP}

Berdasarkan hasil penelitian dan pembahasan yang telah dilakukan, dapat disimpulkan bahwa Project Based learning yang telah diterapkan pada siswa kelas XI MIPA 6, SMA N 1 Bae Kudus berhasil mengembangkan kreativitas melalui produk kreatif teri puter. Adapun rerata kreativitas siswa berada pada kriteria kreatif dan sangat kreatif $(74,3 \%)$, dengan persentase tertinggi pada indikator originality dan terendah pada indikator fluency.

Hasil rerata nilai pengetahuan siswa pada materi asam-basa berada pada kriteria baik dan sangat baik (46\%), cukup baik (40\%), dan kurang baik (14\%). Kemampuan tertinggi pada indikator menghitung $\mathrm{pH}$ larutan asam-basa dan kemampuan terendah pada menghitung konsentrasi $\left[\mathrm{H}^{+}\right]$dan $\left[\mathrm{OH}^{-}\right]$dalam larutan. Dari hasil jawaban siswa, tampak bahwa dalam menyelesaikan soal tes, siswa cenderung lebih mudah menerapkan rumus (jenjang C3) dibandingkan dengan jenjang C4 (menganalisis) ataupun C5 (mengevaluasi).

Meskipun nilai pengetahuan siswa tergolong rendah, namun sebagian besar siswa memberikan respon positif terhadap model pembelajaran yang diterapkan khususnya pada aspek inovasi dan kreativitas dan mengakui bahwa dari sisi aspek pemahaman memang masih rendah.

Berdasarkan hasil yang telah diperoleh menunjukkan masih banyak kelemahan pada penerapan project based learning dengan produk kreatif Teri Puter yang dilakukan. Oleh karena itu masih diperlukan penelitian lebih lanjut tentang model ini supaya mendapatkan hasil yang optimal khususnya dalam memberikan pembekalan pada kreativitas dan pengetahuan siswa.

\section{DAFTAR PUSTAKA}

Aini, Q., Lesmono, A. D., \& Wahyuni, S. (2018). Hasil Belajar, Minat dan Kreativitas Siswa SMA pada Pembelajaran Fisika 
menggunakan Model Project Based Learning dengan Memanfaatkan Bahan Bekas. Jurnal Pembelajaran Fisika, 7(1), 1-7.

Andiyana, M. A., Maya, R., \& Hidayat, W. (2018). Analisis kemampuan berpikir kreatif matematis siswa smp pada materi bangun ruang. Jurnal Pembelajaran Matematika Inovatif, 1(3), , 239-248.

Ariani, L., Sudarmin, \& Nurhayati, S. (2019). Analisis Berpikir Kreatif Pada Penerapan Problem Based Learning Berpendekatan Science, Technology, Engineering, and Mathematics. Jurnal Inovasi Pendidikan Kimia, 13(1) , 2307-2317.

Artikasari, E. A., \& Saefudin, A. A. (2017). Menumbuh Kembangkan Kemampuan Berpikir kretif matematis dengan Contextual Teaching and Learning. Jurnal Math Educator Nusantara, 3(2), 73-82.

Bell, S. (2010). Project-Based Learning for the 21st Century: Skills for the Future. . The Clearing House: A Journal of Educational Strategies, Issues and Ideas, 83(2), 39-43.

Bungay, H., \& Vella-Burrows, T. (2013). The effects of participating in creative activities on the health and well-being of children and young people: A rapid review of the literature. Perspectives in Public Health, 133 (1), 44-52.

Byrge, C., \& Tang, C. ( 2015). Embodied creativity training: Effects on creative self-efficacy and creative production. Thinking Skills and Creativity, 16, 51-61.

Capraro, R., \& Slough, S. (2013). Why PBL? Why STEM? Why now? Rotterdam: Sense Publisher.

Coyne, J., Hollas, T., \& Potter, J. P. (2016). Jumping in: Redefining teaching and learning in physical education through project-based learning. Strategies, 29(1), 4346.

Indriajati, R., \& Ngazizah, N. (2018). Pembelajaran Berbasis Proyek terhadap Kreativitas dan Pemahaman Siswa SD Muhammadiyah
Purworejo. Jurnal Dialektika Jurusan PGSD, 8(2), 111-116.

Jacques, L. A. (2017). What does Project-based Learning (PBL) look like in the mathematics classroom? American Journal of Educational Research, 5(4), 428-433.

Kaufman, J., Plucker, J. A., \& Baer, J. (2008). Essential of Creativity Assessment. Hoboken: John Wiley \& Sons, Inc.

Kenedi. (2017). Pengembangan kreativitas siswa dalam proses pembelajaran di kelas II SMP Negeri 3 Rokan IV Koto. Suara Guru : Jurnal Ilmu Pendidikan Sosial, sains, dan Humaniora 3( 2), 329-347.

Lewis, C., \& Lovatt, P. J. (2013). Breaking away from set patterns of thinking: improvisation and divergent thinking. Thinking Skills \& Creativity. 9, 46-58.

Lynch, M., Sloane, G., Sinclair, C., \& Bassett, R. (2013). Resilience and art in chronic pain. Arts \& Health: An International Journal of Research, Policy and Practice, 5 (1), 51-67.

National Education Association. (2012). Preparing 21st Century Students for a Global Society Great Public Schools for Every Student: An Educator's Guide to the Four C's. Preparing 21st Century Students for a Global Society, $1-38$.

Nuswowati, M., Susilaningsih, E., Ramlawati, \& Kadarwati，S. (2017). Implementation of problem-based learning with green chemistry vision to improve creative thinking skill and students' creative actions. Jurnal Pendidikan IPA Indonesia, 6(2), 221-228.

Prabowo, A. (2012). Pembelajaran Berbasis Proyek Untuk Meningkatkan Pemahaman Mahasiswa atas Permasalahan Statistika pada Perkuliahan Studi Kasus dan Seminar. Jurnal Kreano, 3(2), 1-9.

Rikmasari, R., \& Wati, D. M. (2017). Hubungan persepsi penggunaan media visual gambar (poster) dengan cara berpikir kreatif siswa kelas 3 pada mata pelajaran bahasa indonesia di Bekasi. Jurnal Ilmiah PGSD, 1(1), 30-36. 
Rizawayani, Sari, S. A., \& Safitri, R. (2017). Pengembangan Media Poster Pada Materi Struktur Atom Di SMA Negeri 12 Banda Aceh. Jurnal Pendidikan Sains Indonesia, 5(1), 127-133.

Runco, M., \& Acar, S. (2012). Divergent Thinking as an Indicator of Creative Potential. Creativity Research Journal 24(1), 66-75.

Sumarni, W. (2015). The Strengths and Weaknesses of the Implementation of Project Based Learning: A Review. International Journal of Science and Research (IJSR), 4(3), 478-484.

Sumarni, W., Wardani, S., Sudarmin, S., \& Gupitasari, D. N. (2016). Project Based Learning (PBL) to improve psychomotoric skills: A classroom action research. JPII 5 (2), 157-163.
Sumarni, W.; Wijayati, N; Supanti, S. (2019). Kemampuan kognitif dan berpikir kreatif melalui pembelajaran berbasis proyek berpendekatan STEM. Jurnal Pembelajaran Kimia (JPEK) 4(1), 18-30.

Wijayati, N., Sumarni, W., \& Supanti, S. (2018). Improving student creative thinking skills through project based learning. UICRIC 2018 (pp. 408-421). Semarang: Knowledge E Social Sciences.

Yusandika, A., Istihana, \& Susilawati, E. (2018). Pengembangan Media Poster sebagai Suplemen Pembelajaran Fisika Materi Tata Surya. Indonesian Journal of Science and Mathematics Education 01 (3), 187-196. 